\title{
Trends in Western Ranch Prices and Values
}

MONT H. SAUNDERSON

Highlight: In the 1930's the western stock ranches were generally underdeveloped and underpriced in terms of their potential. Over the past 40 years, however, a number of factors have, in combination, greatly changed this situation. Now, the picture is that of overpricing, and to such a degree as to cause difficult problems in ranch management and in land management.
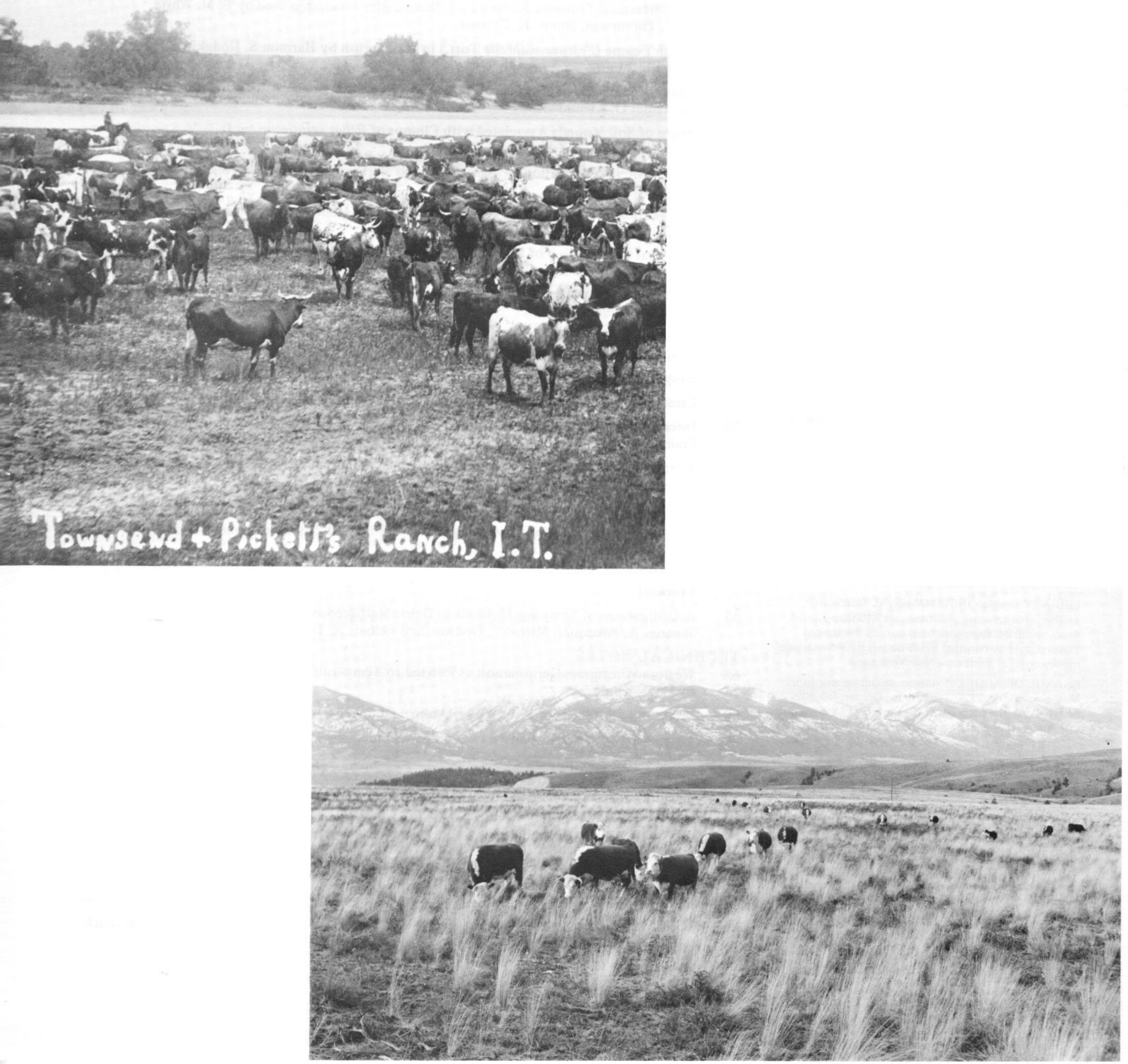
In the early 1930's I heard the chief appraiser for the Farm Credit Administration express the opinion that the long-run "normal" value of the year-round and well-balanced "home for a cow" in western livestock ranch realty should be around $\$ 60$. He was thinking about the lands and physical plant for a wellbalanced ranch of cconomic size with all of the locally suitable complement of the rangelands, the crop lands, the water, and the improvements.

Now, some 40 years later, the prices that are being paid per cow-unit of capacity in western stock ranches are running 10 to 15 times this $\$ 60$ figure. In the more productive ranching areas and in those situations where most of the land being used is deeded land, the investment per cow in recent ranch sales will average nearly 20 times the $\$ 60$ figure. These are the prices for commercial cattle ranches, not for those with some unusual country living appeal, with possible oil prospects, or with rural subdivision and development possibilities. However, all of those things and several others have no doubt had some influence in generating the western stock ranch market and price situation that prevails today.

Not all of this rather spectacular rise since the 1930's in the prices of western livestock ranch realty has come as a result of land speculation and monetary inflation. In the earlier phases of this upward price trend much of the rise was soundly based upon the kinds of ranch development and modernization that resulted in higher unit outputs, in improved product quality, and in substantial gains in cost efficiency.

Much of this development that came during the years following the second World War and into the early 1960's was made possible by sources and types of loan capital not previously available to the western ranches. New lenders became interested in the western ranch loan market and offered longer-term and more suitable types of ranch loan contracts. Some of the productivity gains of the ranches during this period came as a result of the increasing number of younger and more capable managers; and some of the gain in higher unit yields resulted from the fact that after some 15 years of efforts to get the Public Domain

Since 1950 the author has been a private consultant in western stock ranch management and development. He formerly served as a western lands economist with the Forest Service, and from 1925 to 1938 as ranch economist, Montana State University, Bozeman. His current address is Rio Rancho Estates, S. E., New Mexico. under adequate administration, starting with the Taylor Act of 1934, those lands were finally being manlaged and improved.

Some indices of the per-unit gains in production made by western stock ranches since the middle 1940's may be had by analyses of the western states' livestock marketings for the 15-year periods before and following 1945. These data show that during the 15 years from 1930 to 1944 the semidesert ranches of the Intermountain Region were yielding an annual market offtake of between 15 and 20\%. This is to say that for each $1,000 \mathrm{lbs}$., live weight, of stock cattle maintained in herds through the year, the annual marketing of beef would be 150 to 200 lbs., live weight. The comparable figure for the prairie ranches of eastern Montana, Wyoming, Colorado and New Mexico was around 25\% during this period; the comparable index for the ranches of the Rocky Mountain regions, the Sierra foothills, and the coastal mountains of California was around $30 \%$.

A similar analysis of recent livestock marketing data for the western states shows a substantial gain in the market offtake for cattle ranches of all regions of the western states. The largest percentage gain in market offtake has been made by the semidesert ranches of the Intermountain Region. Their annual market offtake has now risen to around 25\%. Probably the most important factor in this output gain by these ranches has been the change from open range usage to individual and group allotment usage and management of the Public Domain. The resulting security of tenure for the users of these lands has made possible the development of water, fencing, and rangeland reseeding. The alloting of the lands by the land administration to individuals and to community groups of users has made possible a much-needed improved husbandry of the herds.

Unit productivity gains resulting from the several aspects of development and modernization of the ranching operations has also been significant for all other western regions and types of livestock ranches. The ranches of the Rocky Mountain regions now have a market offtake of around 35 to $40 \%$ and the prairie ranches now have an annual average market offtake of around $30 \%$. These livestock unit production gains have been accomplished by improved operational and management procedures that result in higher calf crops, lower death losses, and more rapid rates of growth and gain in the young animals. Additionally, there have been income gains due to higher carcass yields and better meat quality as a consequence of improved breeds and better health care.

In addition to the gains in the production output, some important gains have been made, especially in the past 20 years, in the operational cost efficiency of most western livestock ranches. This has come mainly as a result of the mechanization of haying and other crop production and harvesting, of the development and maintenance of range water and fencing, of range reseeding, and irrigation. These benefits have accrued in only a limited way to the small ranches, and as a result there has been considerable consolidation of such ranches.

Nearly all of thesc features of stock ranch modernization and development have required the application of considerably larger amounts of capital. For most ranches, this has had to await the availability of borrowed funds. As previously noted, most of such development has taken place since the end of the last World War.

Not much in long-term amortizable land credit was available to the western livestock ranches, especially those of the 11 western public land states, prior to 1945. The land lending agencies were inclined to view the western stock ranches as having too much in climatic uncertainty and too little in assured land tenure for good lending risk. Too, there were those ranching operations that engaged in considerable buying and selling of livestock through the year, rather than operating a year-round and stable breeding herd operation.

Soon after 1945 this land credit situation began to change rather rapidly as some of the larger life insurance companies and the Federal Land Banks began to study the land credit possibilities in some of the more productive and stable western livestock ranching areas. Some of these institutions had gained ranch lending experience in the better Texas livestock ranching areas and in the Nebraska Sandhills prior to 1945. Soon after 1950 the Federal Land Banks, under new leadership from the Farm Credit Administration, modernized their ranch valuation concepts and loan formulas, and began to compete aggressively with other lending agencies for ranch loans on the basis of long-term and flexible amortization loan contracts.

No doubt this very much increased availability of land credit was a major factor in the development, modernization, and improved economy of western 
stock ranches, particularly those of the 11 western states.

Though this use of a much larger volume of land credit by the western ranches probably was not of itself a generator of inflationary pressures on ranch market prices, it came at a time of inflationary trends in U.S. and world general price levels; consequently it came at a time when large-scale borrowing for improvement and development was advantageous from the standpoint of general price level trends. This was truc not only because of the possibility of repaying the loans with cheaper dollars, but because of the tax advantages that could accrue to the larger-scale borrowers in this situation.

For example, during the middle1950's, a leading lawyer-accountant-tax consultant of one of the western states told an assemblage of livestock association members that currently and for the foreseeable future he saw no reason why stock ranches would have to pay anything much in income taxes. Thus, his recommendation was to borrow heavily for development, classify as much as possible of the development cost as a current annual cost, and anticipate that a continued rise in the U.S. general price level would carry beef cattle prices upward sufficiently to lighten the debt service considerably. Needless to say, this formula has paid rather well for many western ranch owners and buyers.

Because of these and other inflationary pressures, the prices of western livestock ranches have now gone far beyond those of the early development years of the 1950's, when the prices of $\$ 300$ to $\$ 500$ per cow-unit in ranch realty were thought to be high, but probably sustainable. Now the changes of the past 10 years, and especially of the past 5, have generated a ranch price situation far above the values that could be soundly based upon the current and foreseeable earnings capability of the ranches. A few calculations on the level of incomes and operational costs now generally prevailing will illustrate this.

Those ranches with the highest market offtake, principally mountain valley and foothill ranches, now have an annual marketing of around $400 \mathrm{lbs}$., live weight, for each cow-unit maintained in the herds through the year. However, for the breeding herd ranch not all of this $400 \mathrm{lbs}$. will consist of prime young feeder animals. Some of the marketing will be females and aged sires culled from the herd. As a result, though the young animals may sell at live weight prices of $\$ 30$ or more per cwt., the average price received for the 400 lbs. of market offtake will most probably be around $\$ 25$ per cwt. The resulting gross revenue is, then, around $\$ 100$ per cow-unit kept in the herds.

The recurrent annual operating costs for this type of ranch are now $\$ 50$ to $\$ 60$ per cow-unit, before interest. The consequent result is a net revenue of $\$ 40$ to $\$ 50$ per cow-unit. This is the amount available for the interest return upon the investment in land, livestock, and equipment, and for remuneration to the operator for his work and management. Assuming that the ranch has a land indebtedness of $\$ 400$ per cow-unit of capacity, which appears to be a fairly typical figure, plus another $\$ 100$ of indebtedness upon the livestock and equipment, the annual debt service becomes $\$ 30$ per cow-unit at a $6 \%$ rate; and this is with no progress of debt repayment. Thus, we have a margin of $\$ 10$ to $\$ 20$ per cow-unit available for family living from the 300 cow-unit ranch. For such a ranch the probable annual amount for family living is, then, between $\$ 3,000$ and $\$ 6,000$, assuming no financial progress.

There are many ranches whose indebtedness will considerably exceed the averages estimated above. This is more likely to be the situation for the larger ranches. Of 20 recent ranch appraisals taken at random from my files, six have a ranch realty indebtedness within the range of $\$ 600$ to $\$ 750$ per cow-unit.

The factors that have generated the present western stock ranch price situation are too many and too complex for adequate treatment in an article, but a few additional comments will be offered.

The tax advantages that might be realized through the use of borrowed funds to increase the rate of ranch development have already becn noted. Presumably such investment in development should be capitalized in the accounting procedures, but there is always the shadow zone between current and non-recurrent expenditures for ranching development. This type of tax saving was noticed early by non-ranching business operators, who saw the opportunity for what sometimes became a dual tax advantage through the acquisition of stock ranches.

I have observed instances of industrial corporations buying ranches under saleleaseback arrangements, and, through considerable expenditures on the development of the ranches, effect industrialbusiness tax advantages which resulted in the ownership of well-developed ranches within a few years at little or no actual cost to the corporate buyers. This was true even though the buyer contracted for the ranch at full market value at the time of purchase. Because of the saleleaseback arrangement, the buyer did not have to undertake operation and management of the ranch during the contract purchase interim.

The availability of liberal if not excessive credit for ranch purchase and development has been another important factor in the present inflated livestock ranch price situation. During the 1950's and the 1960's, ranch lending agencies were competing actively among themselves for western stock ranch loans, though this has lessened in recent years. Some of the large life insurance companies have been especially aggressive in seeking ranch loans and in many instances have made loans of such size that, had it not been for the continuous uptrend in the ranching property markets, many of the large loans would have been "in trouble."

Another influence in the livestock ranch market price uptrend over the past 20 years has been the buying of ranches for recreational uses, both for the establishment of commercial recreational ranching units and for the establishment of recreational centers for industrial corporation employees. In the latter instance, the livestock enterprise may be continued much as before, and there may be an opportunity for tax savings in the determination of how much employee rest and recreational cost may be treated as part of the ranching enterprise operational cost.

In recent years there has been a growing interest in ranch acquisition by industrial and commercial integration types of buyers. Such buyers are the large-scale feedlot operators seeking continuous availability of uniform lots of animals. The feedlot finishing operations may in turn be owned by livestock slaughtering and processing industries. An illustration of this type of ranch buying is a large feedlot finishing operation that has acquired several mountain valley and foothill ranches for breeding herds, and has also acquired prairie ranches that are used for holding and growing-out the young animals from the breeding herd ranches.

In recent years there has been an increase in the buying interest of the land subdivider-developer-speculator. Such a buyer interest in ranch property is illustrated by the following advertisement which appeared in the Santa Fe, New Mexican: 
WANTED ... RANCH LAND SUITABLE FOR SUBDIVISION. Need 10,000 acres or more of level or gentle rolling land within 50 miles of Santa Fe. Submit maps and details to: /corporation with west coast address].

Many such "developments" have been organized mainly for division and sale to other speculator-buyers with little or no developmental work other than land surveys and tract boundary markers.

The "whither bound" aspect of the present stock ranch price and value situa- tion is something on which I choose not the ranch manager of today faces a to guess. The answers lie to a considerable degree in a number of national economic forces, trends, and administrative actions, and there is no way to forecast these for any appreciable time period. They include such factors as continued regional shifts in population, the continued availability of large amounts of land credit, the continuation of a high level of economic activity and income, and the continued inflation of the general price level. Whatever the future trends may be, situation full of hazards. I hardly need add that the ranch owner and operator who must pay interest upon any substantial part of today's ranch values has an uphill job in making an adequate familyliving income from a ranching enterprise. What appears to have been happening is that in the ranch credit or budgeting for the annual funds, the possible future capital value growth of the ranch has been anticipated in the provisions made in the annual funds for family living. 